\title{
The innovative development of machine building as a driver of import substitution
}

\author{
Sergey Zhironkin ${ }^{* 1}$, Magerram Gasanov ${ }^{1}$, Galina Barysheva ${ }^{1}$, Konstantin Kolotov ${ }^{2}$, and \\ Olga Zhironkina ${ }^{3}$ \\ ${ }^{1}$ Tomsk Polytechnic University, Department of Economics, 634050, 30 Lenina st., Tomsk, Russia \\ ${ }^{2}$ Tomsk Polytechnic University, Post-Graduate Study, 634050, 30 Lenina st., Tomsk, Russia \\ ${ }^{3}$ Kemerovo institute (branch) of Plekhanov Russian University of Economics, Department of \\ Humanities, 650992, 39 Kuznetsky av., Kemerovo, Russia
}

\begin{abstract}
Within the rent-and-raw material model of Russian economy the state's attempts to stimulate import substitution do not generate innovative type of economic development and rebuilding of its industrial sector, competitiveness on the domestic market. In high entropy of market processes it becomes obvious that without recovery of effective global production chains in Russian economy the risks of economic and geopolitical security of Russia, the final loss of Russian technological identity, the loss of international competitiveness and securing raw material vector of long-term social and economic development are increasing. Therefore, it is machine building, as an industry, being a member of most production chains must become a driver of import substitution. Innovative development of machine building is especially in demand in such industrialized region as Kuzbass. Its major industries coal, metallurgical, chemical - are in need of machinery products. The article describes the features and tools of machine building innovative development.
\end{abstract}

\section{Introduction}

In economy of Kuzbass (old industrial Russian region), despite the high level of urbanization and concentration of basic industries, the problems of imports that are typical for Russian economy as a whole are increasing. They form a complex of negative processes in the region, holding the production of competitive output of raw materials processing, stabilization of employment and budget revenues, and social wellbeing growth [1].

\section{Material and Method}

The solution of the problems of regional economy requires the development of import substitution, which should be initiated in the regional machine building industry: - the transmission of external shocks in reducing financial stability of basic for Kuzbass

\footnotetext{
* Corresponding author: zhironkin@tpu.ru
} 
industries enterprises - coal, chemical, metallurgical. As evidence can serve a high proportion of lossmaking medium and large enterprises the proportion of which increases when raw material prices on the world market are decreasing [2]. So, in the region this figure was $32.6 \%$ in $2005,36.1 \%$ in $2008,31.1 \%$ in 2011 and $38.1 \%$ in 2014 . The fact that more than a third of industrial enterprises in the Kemerovo region are unprofitable indicates under-use of the domestic demand potential for smoothing fluctuations of negative foreign economic conditions;

- continuing import growth of production means by the enterprises dominating in the region coal industry along with the recovery of coal production since the beginning of the 2000s;

- non-innovative development of the regional economy, resulting in enhancing its dependence on the global raw material market. Thus, according to the government program of the Kemerovo region "Economic development and innovative economy of Kuzbass for 2014-2016" the share of innovative goods and services in total sales of Kuzbass enterprises decreased from $1.7 \%$ to $1.4 \%$ (with minimum 1.1\% in 2009) from 2006 till 2012 . This is in 8-9 times less than in the countries of Eastern Europe and in 12-13 times less than in Germany and the United States;

- raw material export growth, along with an increase of processed products import. In particular, the enterprises of Kuzbass coal industry are exporting to South-East Asia up to $15 \%$ of coal mined in the region. At the same time the plastic products import from these countries cover $70 \%$ of the regional consumption.

The comparative dynamics of production and export of coal, metal, on the one hand, and machinery import, on the other hand, illustrates the complex problems of neo-industrial import substitution in Kuzbass [3].

The sustainable growth of coal mining in the region (for $109 \%$ over the period 19982015 ) is accompanied, on the one hand, with the accelerated replacement of production means for coal mines and quarries. On the other hand, since 2003, as the consequences of ruble devaluation in 1998-1999 are over, faster growth of machinery import (in 4 times in 2002-2012) is observed in Kuzbass. In 2014, a new round of devaluation led to a drop in the regional machine building import (from 1360 to $\$ 322$ million), but in 2015 its volume grew by $8 \%$.

Under these conditions the production volume of machinery in Kuzbass has been declining since 2011 against the unstable investment background. At the same time, the main export-oriented industries of Kemerovo region economy - coal and metallurgical - are increasing their exports (in particular, the export of Kuzbass coal for 1998-2015 had increased tenfold.). This demonstrates the high potential demand for the means of production for the basic industries of Kuzbass economy, which is met today mainly due to the import [4].

In Kemerovo region economy mining and basic industries dominate. In 2014 their share in the gross regional product (GRP) were respectively: the fuel industry - $36.8 \%$, ferrous and nonferrous metallurgy $-29.1 \%$, chemical industry $-7,0 \%$, machinery $-3,2 \%$. And the peculiarity of Kuzbass machine building is targeting most of its enterprises to the needs of the dominant regional industries, mainly coal and chemical.

\section{Results and discussion}

Machine building is that branch which neo-industrial transformations of the regional economy depend on [5-7]. Their starting point should be the technological modernization of extracting and basic industries. At the same time, from the beginning of market reforms the entire machine building industry in the Kemerovo region is experiencing significant problems and cannot get the role of a "catalyst" of neo-industrial transformation [8-12]. 
First, before market reforms machine building industry was a technological leader and one of the main branches of Kuzbass economy, having produced up to $14 \%$ of the GRP in 1988-1992. By now there are such major machine building companies as JSC "Anzheromash", LLC "Yurmash", JSC "Sibtenzopribor", JSC "Elektromash-M", LLC "Kemerovohimmash", "Razvitie" operating in the region. They account for $10 \%$ of the regional industrial production and $11 \%$ of the total value of fixed assets in the region.

Secondly, after almost five-time decrease of the machine building share in GRP for 1998-2015, since 2011 there has been a steady decline in the volume of machinery production - as a result of reduced demand from the regional coal, metallurgical, chemical, power companies as well as unstable investments.

Third, the growth of import-dependence of the key industry of Kemerovo region economy - coal - takes place against the background of the progressive increase in volume of coal mining in the region by $123 \%$ over the period 1998-2015 from 94 million tons to 215 million tons.

The share of import in the equipment used in coal mining in Kuzbass reaches $27 \%$ for some types of products. At the same time $60 \%$ of mining equipment is imported from the "sanction" countries - the US, EU and Australia.

Particularly acute need for import substitution of mining equipment for Kuzbass machine builders creates considerable deterioration of used domestic means of production and the dominance of import in the least deteriorated part of it. Thus, major open pit mining equipment (excavators, drilling machines, pumps, transformer stations) are deteriorated more than $70 \%$, while the most part of the equipment purchased during the last 10 years and having a deterioration rate of less than $30 \%$ had been imported.

Problems preventing the development of import substitution in Kuzbass economy also appear to be obstacles on the way of its neo-industrial development, which should begin with the innovative development of the basic industries. These problems are connected with the lack of global competitiveness of the regional companies' products, with the lack of investments into modernization of new equipment output within the region, with undeveloped institutions' integration among research organizations, industrial enterprises, investors in the process of neo-industrial import substitution.

In Kuzbass there is a certain reserve for the formation of institutes necessary for initiating neo-industrial import substitution. In particular, in the region the Coordination center for the development of import substitution and the Regional plan and the list of investment projects in this area were set up.

The issues of import substitution are not reflected in such an important document as the "Strategy of social and economic development of the Kemerovo region up to 2025 (Kuzbass-2015)". Meanwhile, in Section 2.1.3 of the strategy "The risk of technological backwardness of the region" the replacement of the domestic machine building products by the imported ones is clearly indicated: "there is a dangerous situation in which the coal industry begins to depend on foreign suppliers of equipment, spare parts and accessories. According to experts, this is largely due to the practice of so-called "bound" foreign loans, which are burdened by the conditions of purchase exceptionally import equipment."

Also, the Strategy "Kuzbass 2015" lacks the link between the growth of living standards in Kuzbass and modernization and import substitution in the basic industries through the increased productivity and new jobs in machine building, radio electronics and professional equipment, chemical industry.

Therefore, to solve regional problems of neo-industrial import substitution it is necessary to take into account the specifics of the industry structure and the state of productive forces as well as the role of import substitution potential of the industries initiating neo-industrialization of economy. These industries must ensure technological modernization, first of all, extractive and basic industries, which, in turn, will create a basis 
for import substitution of products in manufacturing and high-tech industries.

With regard to Kemerovo region economy, machine building stands for such industry, in particular its segment producing equipment for mining companies. Concerning this, it is advisable to create neo-industrial import substitution cluster in Kuzbass, oriented to the following tasks solution:

1. Radical reconstruction, technical and technological modernization of industrial regional enterprises, many of which were created in 1960-70ies and have fixed capital depreciation level of about $70 \%$. At the same time for the whole period of market reforms there was no mass replacement of the production means in Kuzbass machine building that enhances the technological gap between the regional producers and foreign competitors, and complicates the start of import substitution.

2. Breaking the vicious circle of investment and production problems: a significant physical deterioration of fixed capital - reducing the international competitiveness of machine building output - decreasing of sales - the lack of investment resources for the modernization of production - further increase in physical deterioration. This requires the formation of the Single investment program of regional machine building, reflecting the needs of coal, chemical, iron and steel industries in new equipment, credit and investment opportunities of banks and investment companies, as well as technological possibilities of machine building enterprises.

3. Increasing of machine building regional companies' cooperation, which is now estimated at least $10 \%$, and overcoming their technological disunity. This is particularly important for the production of equipment and production systems with predetermined properties and output with a definite purpose competitive on the regional market. An important role in the development of cooperative relationships within the cluster plays nonprofit organization "Association of Kuzbass machine builders" which brings together about thirty machine building enterprises from Kemerovo, Novosibirsk and Tomsk regions.

The formation of neo-industrial import substitution machine building cluster in Kuzbass should include the following activities of the interested parties - coal, machine building enterprises, the regional authorities, research, design and educational organizations.

Firstly, the analysis of technological conditions for machine building enterprises' modernization necessary for import substitution of the equipment for the coal industry, considering the possibilities of inter-firm cooperation should be made. Also it is necessary to analyze investment needs and financial possibilities of the banks and investment companies represented in the region. The result of this analysis should become the basis for the Development strategy of Kuzbass neo-industrial import substitution cluster of machine building.

Secondly, the list of cluster's residents, which includes machine building companies as well as the regional subjects of financial, research and educational spheres, should be compiled. In addition, it is necessary to make partnership agreements with foreign developers of modern machine building technologies, computer software on assignment of property rights, patents and licenses.

Third, it is advisable to make the complex offer of modern machine building products for the needs of coal and other industries of Kuzbass economy capable in the medium term to replace foreign equipment. This, in turn, should be the logical modernization outcome of the regional machine building complex, and involves the implementation of the following actions:

- the organization of the investment consortium, which would include the main consumers of machinery products - enterprises of coal, chemical and machine building industries, making parity investment pool in regional machine building;

- the establishment of research-and-production and engineering firms' network in the industry with participation of the leading international manufacturers of machinery 
equipment;

- the establishment of a regional agency to attract and protect investments in import substitution of industrial output, the main focus of which should made on the machine building industry initiating neo-industrialization;

- the structuring of a guarantee investment fund in machinery, the main role in which should be played by the regional authorities.

Fourthly, the list of regional tax exemptions for the residents of import substitution machine building cluster should be compiled.

Currently, there is an urgent need in developing the complex regional target program of neo-industrial import substitution in Kuzbass industry. The program should link the intensification of R\&D, investments in modernization of coal, chemical and machine building industries, professional equipment, government support and loan financing guarantees for the enterprises. The main objective of this program should become the adjustment of the target for the import substitution level of technology in these industries and the level of imported by Kuzbass enterprises equipment.

\section{Conclusion}

The development of neo-industrial import substitution requires setting up the innovative and industrial clusters of a special network type, where companies, research organizations from different clusters would be merged into a single research-and-production complex on the basis of technological platform of import substitution. Innovative and industrial infrastructure should become the unifying elements, as well as investment projects for the production of import substitution output, covering all the residents of the cluster.

\section{References}

1. A. A. Khoreshok, S. A. Zhironkin, M. A. Tyulenev, G. A. Barysheva, V. Yu. Blumenstein, M. C. Hellmer, S. V. Potyagailov, IOP Conf. Ser.: Mater. Sci. Eng., 142, 012122 (2016)

2. G. Barysheva, I. Kashchuk, Procedia Soc. Behav. Sci., 166, 62 (2015)

3. V.A. Trifonov, V. A. Shabashev, and I. V. Dobrycheva, EpSBS, VII, 346 (2016)

4. M. I. Agienko, E. P. Bondareva, G. V. Chistyakova, O. V. Zhironkina, and O. I. Kalinina, IOP Conf. Ser.: Mater. Sci. Eng., 142, 012022 (2016)

5. D. Bell, The coming of post-industrial society. Venture in social forecasting (Collman Pub., New York, 1973)

6. C. Clark, The conditions of economic progress (Logan Pub., London, 1991)

7. R. Reich, The work of nations. Preparing ourselves for 21st Century capitalism (Penguin Pub., New York, 1992)

8. J. Kretschmann, A. B. Efremenkov, and A. A. Khoreshok, IOP Conf. Ser.: Mater. Sci. Eng., 142, 012124 (2016)

9. V.A. Gogolin, Y.A. Ryzhkov, Soviet Mining Science 17, 156 (1981)

10. V. Aksenov, A. Khoreshok, V. Beglyakov, App. Mech. and Mat., 379, 20 (2013)

11. V.A. Gogolin, Y.A. Ryzhkov, Soviet Mining Science, 13, 17 (1977)

12. V. Kovalev, B. Gerike, A. Khoreshok, P. Gerike, Mining 2014: Taishan academic forum - Project on mine disaster prevention and control (Atlantis Press, Paris, 2014) 